\title{
The principles of justification of an object construction duration
}

\author{
Pavel Oleinik ${ }^{1}$, Nadezhda Cherednichenko ${ }^{1,}$, , Stefan Shvedov $^{1}$, and Vitaliy Melnichuk ${ }^{1}$ \\ ${ }^{1}$ Moscow State University of Civil Engineering, 26, Yaroslavskoye sh., Moscow, 129337, Russia
}

\begin{abstract}
The duration of an object construction is considered as a parameter expressing the concentrated influence of all stages of its formation, including design, preconstruction, construction, etc. It is shown that the construction stage, as the final stage, is the most flexible and its components that include organization of construction, technology and mechanization of construction and installation works promptly implement solutions from all previous stages, consisting of a large number of various methods and ways of influencing the construction duration. These activities allow reducing energy costs and making production less energy intensive. The decisions on combining the work of the preconstruction and the main periods of construction are given as an example.
\end{abstract}

\section{Introduction}

The object construction includes the stages of pre-project preparation, design, preconstruction, construction, and development of design capacity. Moreover, almost every stage consists of a series of sub-steps. For example, the design phase is divided into the following main stages: preparation of a design assignment, project development, examination, project approval, development of working documentation. Its duration is established at each stage and sub-stage on the basis of the relevant norms or directives. It should be noted that the most difficult procedure is to establish the total duration of an object construction, since in this case it is necessary to establish the degree of combining stages with each other taking into account a variety of factors: the minimum and maximum degree of admissibility of the combination, technical and economic feasibility, development of raw materials and related industries etc. $[1-6]$.

\section{Materials and Methods}

In 1983, the "Common Standards for the Duration of Design and Construction of Enterprises, Buildings and Structures and Development of Designed Capacities" were issued. They were approved by the Decree of the USSR State Committee for Construction and the USSR State Planning Committee on December 31, 1982 No. 314/309 [1]. These standards covered the period from the date for the work, established by the schedule to the contract for the design and survey work, to sustainable production and were intended for

\footnotetext{
${ }^{*}$ Corresponding author: CherednichenkoND@mgsu.ru
} 
almost all mining and processing industries (Table 1). According to the calculations of specialists, the application of the Uniform Norms should have ensured a reduction in the total duration of the investment cycle by 1.5-2.0 times. In its turn it allowed saving about 25 million rubles for one billion capital investments per year.

The writing of norms took into account a number of progressive decisions. So, in the case of making a decision on the detailed design for the volume of construction and installation work of the first year of the construction and the performance of the preconstruction before the project's approval, the normative duration of an object construction was reduced by combining thedetailed design with the project expertise, as well as by eliminating the gap between the end of the detailed design and the commencement of construction.

Such norms are necessary in long-term planning for the development of industries and individual regions, but, unfortunately, they did not go anywhere.

Table 1. Uniform norms of the total duration of the construction of production capacities (fragment).

\begin{tabular}{|c|c|c|c|c|c|c|c|c|c|c|c|c|}
\hline \multirow{5}{*}{ Nameofobject } & \multirow{5}{*}{$\begin{array}{l}\text { Characteristic, } \\
\text { capacity }\end{array}$} & \multicolumn{11}{|c|}{$\begin{array}{l}\text { Uniform rate of the duration of design, construction and } \\
\text { development, months }\end{array}$} \\
\hline & & \multirow{4}{*}{$\begin{array}{l}\text { In } \\
\text { total }\end{array}$} & \multicolumn{10}{|c|}{ Including duration of } \\
\hline & & & \multicolumn{4}{|c|}{ design } & \multicolumn{5}{|c|}{ construction } & \multirow[b]{3}{*}{ 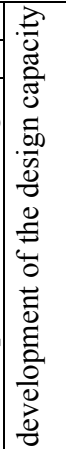 } \\
\hline & & & & & cludi & & & & incl & uding & & \\
\hline & & & 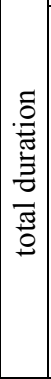 & 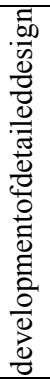 & 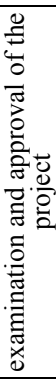 & 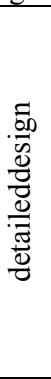 & 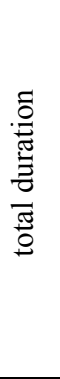 & 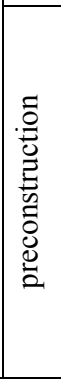 & 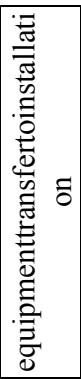 & 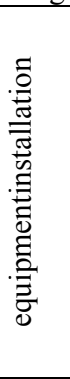 & 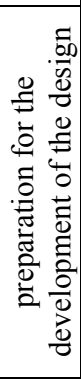 & \\
\hline 1 & 2 & 3 & 4 & 5 & 6 & 7 & 8 & 9 & 10 & 11 & 12 & 13 \\
\hline \multicolumn{13}{|c|}{ Mineral fertilizers production } \\
\hline $\begin{array}{l}\text { 1. } \\
\text { Ammoniaproduction }\end{array}$ & $\begin{array}{l}\text { Capacity of } 450 \\
\text { thousand tons / } \\
\text { year (in one unit) }\end{array}$ & 75 & 27 & $\begin{array}{l}11 \\
1- \\
11\end{array}$ & $\begin{array}{c}3 \\
12- \\
14 \\
\end{array}$ & $\begin{array}{l}13 \\
15- \\
27\end{array}$ & $\begin{array}{r}30 \\
34- \\
63\end{array}$ & $\begin{array}{c}4 \\
34- \\
37\end{array}$ & $\begin{array}{c}39- \\
57\end{array}$ & $\begin{array}{c}20 \\
42- \\
61\end{array}$ & $\begin{array}{c}2 \\
62- \\
63\end{array}$ & $\begin{array}{c}12 \\
64- \\
75\end{array}$ \\
\hline $\begin{array}{l}\text { 2. Production of } \\
\text { weak nitric acid }\end{array}$ & $\begin{array}{l}\text { Capacity of } 360 \\
\text { thousand tons / } \\
\text { year. } \\
\text { Three units with } \\
\text { a capacity of } 120 \\
\text { thousand tons / } \\
\text { year under } \\
\text { pressure of } 740 \\
\text { kPa (7.3 } \\
\text { atmospheres) }\end{array}$ & 60 & 24 & $\begin{array}{c}8 \\
1-8\end{array}$ & $\begin{array}{l}3 \\
9- \\
11\end{array}$ & $\begin{array}{c}13 \\
12- \\
24\end{array}$ & $\begin{array}{c}24 \\
31- \\
54\end{array}$ & $\begin{array}{c}3 \\
31- \\
33\end{array}$ & $\begin{array}{c}36- \\
48\end{array}$ & $\begin{array}{c}15 \\
38- \\
52\end{array}$ & $\begin{array}{c}2 \\
53- \\
54\end{array}$ & $\begin{array}{c}6 \\
55- \\
60\end{array}$ \\
\hline
\end{tabular}

Thus, the task of determining the duration of an object construction and any of its stages requires a reasonable account of the totality of 50 factors, extending the duration of the construction $[3,8]$. At the same time, some factors are characteristic of individual stages, while others influence during the entire investment process.

Theoretical studies and the vast experience of both domestic and foreign practices in the construction of enterprises, buildings and structures make it possible to identify the main directions of development and enhancement of the validity of the object construction duration. It is appropriate to note that an object construction duration is a concentrated 
expression of the influence of all stages of its formation, including the possibilities of planning organization of a land plot, architectural, structural and space-planning decisions, decisions on engineering equipment and engineering and technical support, organization of construction, technology and mechanization of installation work.

As a rule, the possibilities of planning organization of a land plot are decided on preproject preparation and cannot be changed after the legal documents are completed. As for the architectural, structural and space-planning decisions, as well as decisions on engineering equipment and engineering and technical support, making corrections can be resulted in serious changes in design decisions and estimated cost, followed by a new project review and in suspending construction at least for this period.

In terms of impact on the object construction duration organization of construction, technology and mechanization of construction and installation works are the most flexible factors.

The impact of the construction organization is expressed through the adjustment of time schedules and the use of personnel and construction equipment. Thus, the adjustment of the time schedule is performed by redistributing workers and construction equipment. The need for such an adjustment arises, as a rule, in cases of inconsistency between the construction duration and regulatory or directive indicators, insufficient labor and technical resources, unfavorable working conditions, etc. At the same time the necessary condition of recalculation is observed - the achievement of continuous and uniform movement of workers on the object or from object to object, providing for maximum productivity $[2,7]$.

The choice of technology of construction and installation works depends on the characteristics of the structures and space-planning decisions. As a rule, there are always several options for performing the process and the solution is usually chosen depending on the scientific and technical level of the contracting construction organization. However, in the construction of objects with particularly complex structures and methods of work, there is a mandatory need to use special tools and devices, without which the construction is impossible. For example, the use of progressive methods of block installation of structures and technological equipment is possible only in the construction of special stands with paved railways or highways for the supply of node points and integrated blocks.

In this case, the installation consists of four stages:

acceptance of equipment units, metal structures and pipelines at the customer's site from customer, their revision;

pre-assembly of equipment, metal structures and pipelines;

supply of unitized units to the installation area and their installation in the design position;

installation of unitized units using cranes of large load capacity.

Lifting gear and devices for transportation and installation of unique equipment and oversized heavy blocks, sheet piling barriers, various devices for moving buildings, sliding and permanent forms are used in construction very often.

In such cases, the customer is obliged to involve specialized design and engineering organizations for the development of working drawings, despite it increases the estimated cost of construction, but at the same time significantly reduces its duration and significantly improves the quality of construction products.

The choice of the necessary means of mechanization of construction and installation works depends primarily on the adopted method of the basic technological operations and the technical and economic parameters of construction machines. Machines with high operational performance are usually used in the process of production of various types of construction and installation works. But at the same time, the formation of a set of machines is also affected by the influence of working conditions - constraints on the 
construction site, work in enclosed spaces, natural and climatic conditions (northern and southern areas, mountainous terrain, etc.).

Thus, for each stage of an object construction there are its own objective prerequisites and possibilities to influence the duration of the investment process. Such influence is shown in Table 2.

Table 2. The impact of decisions on an object construction duration.

\begin{tabular}{|c|c|c|c|c|c|c|}
\hline \multirow[b]{3}{*}{ Stage } & \multirow[b]{3}{*}{ Type of decision } & \multicolumn{5}{|c|}{ Influence on duration } \\
\hline & & \multicolumn{5}{|c|}{ including the stages } \\
\hline & & preparatory & project & preconstruction & construction & $\begin{array}{c}\text { reaching } \\
\text { a } \\
\text { capacity }\end{array}$ \\
\hline Pre-project & $\begin{array}{l}\text { Planning organization of } \\
\text { the land plot }\end{array}$ & & + & + & + & \\
\hline \multirow[b]{3}{*}{ Design } & $\begin{array}{l}\text { rchitectural, space- } \\
\text { planning, constructive }\end{array}$ & & + & & & \\
\hline & engineeringinfrastructure & & + & & & \\
\hline & \begin{tabular}{|l|}
$\begin{array}{l}\text { Construction } \\
\text { organization }\end{array}$ \\
\end{tabular} & & + & + & & \\
\hline \multirow{2}{*}{$\begin{array}{l}\text { Preparation } \\
\text { for } \\
\text { construction }\end{array}$} & $\begin{array}{l}\text { Organization and } \\
\text { technological }\end{array}$ & & & + & + & \\
\hline & Preconstruction & & & + & + & \\
\hline \multirow[b]{2}{*}{ Construction } & $\begin{array}{l}\text { Implementation of } \\
\text { decisions on construction } \\
\text { production organization }\end{array}$ & & & & + & + \\
\hline & $\begin{array}{l}\text { Implementation of } \\
\text { decisions on the } \\
\text { technology and } \\
\text { mechanization of } \\
\text { construction and } \\
\text { installation works }\end{array}$ & & & & + & + \\
\hline
\end{tabular}

It should be noted that the influence is characterized by the transfer of the fundamental "functions" of space-planning and constructive decisions to the sphere of construction production. Therefore, it is precisely the organization of the construction industry, the technology and the mechanization of construction and installation works that are the main "respondents" for meeting the construction deadlines.

At the same time, at the stage of construction production there is a large number of levers for optimizing the duration of construction. As an example, consider the possibility of combining the work of the preconstruction and the main periods of construction.

\section{Results and discussions}

The duration of the preconstruction varies over a wide range and during construction of residential buildings amounts to $8.1-22.2 \%$ of the total duration, of preschool institutions $12.9-31.3 \%$, of health care facilities $-7.5-18.1 \%$, of communal buildings $-14.2-20.8 \%$, etc. Studies [3, 9-11] proved that in one part of the construction site, the preconstruction work should always be carried out before main work, and in the other part of the territory the work can be carried out in combination.

This territory consists of sections with utilities in non-installation zones. There is a third part of the territory of the construction site with communications and the foundations of buildings and structures with combined excavation sites. With a high built-up density, the 
work in this area should be carried out before the main period, and at a low built-up density, on the contrary, it should be carried out during the main construction period:

$$
V_{p}^{D}=\left(0.54 P+0.48 P^{0,447}\right) V_{p}
$$

at $P \leq 0,71$

$$
\begin{aligned}
V_{p}^{\mathrm{C}}= & \left(1-0.54 P-0.48 P^{0,447}\right) V_{p} \\
& V_{p}^{D}=(1-0.29 P) V_{p}
\end{aligned}
$$

at $P>0,71$

$$
V_{p}^{\mathrm{C}}=0.29 P V_{p},
$$

Where $V_{p}, V_{p}^{D}, V_{p}^{\mathrm{C}}$ is the scope of the preconstruction period, respectively, the total work, carried out before the main construction and installation works, in combination with the main construction and installation works;

$P$ is the building factor:

$$
P=\frac{F}{S}
$$

Where: $F$ is the building area; $S$ is the size of the building in a fence.

According to the calculations, a certain part of the preconstruction work at an appropriate built-up density can be performed during the main construction period (Table 3 ). As a result of this combination of preconstruction and main construction and installation work, the construction duration is reduced accordingly.

Table 3. Relative indicators of preconstruction work in the main construction period.

\begin{tabular}{|c|c|c|c|c|c|c|c|c|c|}
\hline $\mathrm{P}$ & 0.1 & 0.2 & 0.3 & 0.4 & 0.5 & 0.6 & 0.7 & 0.8 & 0.9 \\
\hline $\mathrm{V}_{\mathrm{p}}^{\mathrm{C}}$ & 0.77 & 0.65 & 0.56 & 0.46 & 0.38 & 0.30 & 0.21 & 0.23 & 0.26 \\
\hline
\end{tabular}

\section{Conclusions}

Improving the validity of an object construction duration is extremely relevant task due to the influence of characteristics of the object and the conditions of work production. This should take into account the constant dynamics of changes in the materials, structures and equipment are being used, as well as the methods and forms of design, preparation and construction of enterprises, buildings and structures.

The analysis showed that the most flexible elements of influence on an object construction duration are the organization of construction production, technology and mechanization of construction and installation works as the final stage of all previous stages. Therefore, in this stage there are a lot of methods for reduction and extension of an object construction duration.

One of the active factors of these methods is the combination of a number of preconstruction works with the main construction and installation works. In particular, with an average built-up density the volume of such works will be 0.34 , and with a high built-up density -0.23 .

\section{References}

1. Uniform standards for the duration of the design and construction of enterprises, buildings and structures and the development of design capacity (Moscow, 1983) 
2. P.P. Oleynik, Natural and Technical Sciences 10, 412-414 (2015)

3. P.P. Oleynik, Organization of construction production (Moscow, 2010)

4. Provision on a unifrorm procedure for pre-project and project preconstruction work in Moscow (Moscow, 2000)

5. L.V. Kievskiy, Urban development (Moscow, 2014)

6. B.Ph. Shirshikov, A.M. Slavin, Industrial and Civil Construction 8, $92-95$ (2016)

7. B.Ph. Shirshikov, A.M. Slavin, V.S. Stepanova, S.O. Mikheev, Industrial and Civil Construction 3, 70-75 (2016)

8. P.P. Oleinik, T.K. Kuzmina, V. Zenov, MATEC Web of Conferences 86, 05019 (2016)

9. P.P. Oleinik, T.K. Kuzmina, MATEC Web of Conferences 117, 00129 (2017)

10. I.V. Ilin, V.I. Koposov, A.I. Levina, Life Science Journal. Vol. 11, Issue 11, 265-269 (2014)

11. I. Ilin,, A. Levina, O. Iliashenko, MATEC Web of Conferences, 106, Article number 08066. (2017) doi:10.1051/matecconf/201710608066 